p-ISSN 1693-1246

e-ISSN 2355-3812

January 2019
Jurnal Pendidikan Fisika Indonesia 15 (1) (2019) 29-38

DOI: 10.15294/jpfi.v15i1.19308

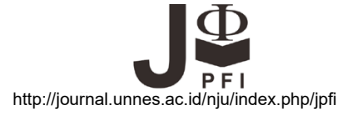

\title{
Development of Ultrasonic Sensors Based Mechanical Energy Experiments
}

\author{
B. Subali*, Z. Lu’aili, I. Sumpono
}

Program Studi Pendidikan Fisika, Universitas Negeri Semarang, Indonesia

Submitted: 20 Agust 2018. Revised: 11 December 2018. Accepted: 1 January 2019

\begin{abstract}
Energy is one of the basic concepts in physics which is included as an abstract concept that is not easily captured by students to its physical properties. Therefore it is necessary to optimize the experimental tool in physics learning, especially in the learning of mechanical energy to facilitate understanding the concept. Technology research is growing rapidly and is able to contextually present abstract phenomena that are sensor-based technology and one of them is an ultrasonic sensor. This study aims to develop a mechanical energy experimental tool using ultrasonic sensors to facilitate students in understanding the concept of energy. The development of the experimental tool used research and development methods. To test the feasibility of the experimental tool developed and the accompanying practicum module, a series of feasibility tests have been carried out including calibration tests, feasibility tests by physicists, and empirical tests by users. The instrument used is a checklist item compiled based on the standard indicators of the feasibility of an experimental tool. The results of the development showed that the experimental tool had a precision percentage of $98.1 \%$ and a high accuracy of $99.99 \%$ with a value of $t=\left(0.383 \pm 383 \times 10^{-4}\right) \mathrm{s}$. Based on the feasibility test by physicists $93.75 \%$ of indicators as standardized experimental tools have been achieved, as well as the experimental modules fulfilling $90.90 \%$ of the standard set. Similar results were also report by users that the experimental tool was feasible to be used in schools' level, but there were still obstacles related to the sensitive nature of ultrasonic sensors with surrounding movements and constraints in making variable variations to be tested which had an impact on the less optimal graphic display.
\end{abstract}

\section{ABSTRAK}

Energi merupakan salah satu konsep dasar fisika yang memiliki sifat abstrakyang sulit ditangkap makna fisisnya oleh siswa. Oleh sebab itu diperlukan optimalisasi alat eksperimen dalam pembelajaran fisika khususnya dalam pembelajaran energi mekanik untuk mempermudah pemahaman konsep tersebut. Penelitian bidang teknologi yang berkembang pesat dan mampu menghadirkan secara kontekstual fenomena yang abstrak adalah teknologi berbasis sensor dan salah satunya adalah sensor ultrasonik. Penelitian ini bertujuan untuk mengembangkan alat eksperimen energi mekanik dengan menggunakan sensor ultrasonik untuk memfasilitasi siswa dalam memahami konsep energi. Pengembangan alat eksperimen ini menggunakan metode research and development. Untuk menguji kelayakan alat eksperimen yang dikembangkan dan modul praktikum yang menyertainya, maka telah dilakukan serangkaian uji kelayakan termasuk uji kalibrasi, uji kelayakan oleh ahli fisika, dan uji empiris oleh pengguna. Instrumen yang digunakan adalah item checklist yang disusun berdasarkan indikator baku kelayakan suatu alat eksperimen. Hasil pengembangan alat eksperimen energi mekanik berbasis sensor ultrasonik yang telah dilakukan menunjukkan bahwa alat eksperimen tersebut memiliki persentase ketepatan sebesar $98,1 \%$ dan ketelitian yang tinggi sebesar $99,99 \%$ dengan nilai $t=\left(0,383 \pm 383 \times 10^{-4}\right) \mathrm{s}$. Berdasarkan uji kelayakan oleh ahli fisika didapatkan $93,75 \%$ indikator sebagai alat eksperimen terstandar telah tercapai, demikian juga dengan modul eksperimennya memenuhi persentase $90,90 \%$ dari standar yang ditetapkan. Hasil senada juga ditemukan oleh pengguna bahwa alat eksperimen tersebut layak untuk digunakan dalam kegiatan eksperimen di sekolah, namun masih terdapat kendala terkait sifat sensitif sensor ultrasonik dengan pergerakan sekitar dan kendala dalam melakukan variasi variabel yang akan diujikan yang berdampak pada kurang optimalnya tampilan grafik.

Keywords: Experiment Tools; Mechanical Energy; Ultrasonics Sensor

${ }^{\star}$ Correspondence Address:

Kampus Sekaran, Gunungpati, Semarang 50229, Indonesia

E-mail : bambangfisika@mail.unnes.ac.id 


\section{INTRODUCTION}

Physics is one of the fields of science which discussing nature and its symptoms, from the real to the abstract concepts, and frequently involves mental models to understand the concept (Setiawan, Sutarto \& Indrawati, 2012). According to Rosenblum and Kuttner (2006), there are obstacles faced in learning physics in conveying abstract concepts. This condition puts physics as a subject that is less attractive to students. It is not easy for students to directly associate abstract concepts in physics with similar concepts that already exist in their daily lives. Therefore, the development of science and technology is needed to be able to cover the discussion of abstract concepts in physics learning.

Physics learning is not only aimed at conveying theories and formulas to memorize, but also attempts to explain natural phenomena and natural processes through the discovery and presentation of facts (Awal, Ahmad \& Bunga, 2012). According to Suparno (2007), students will get a better understanding of the concept of physics if the teacher gives them the opportunity to discover the concept themselves. Confucius also said as quoted in Silberman (2006), that "what I do, I understand." The qoute implies that students will be able to understand physics better, one of which can be obtained through experiments in laboratory.

The laboratory can be used as a site for students to verify the concepts learned to have a stronger understanding. However, the teacher can also use the laboratory as a vehicle to find ideas, stimulate the curiosity of students, carry out scientific work on the discovery of concepts so that understanding the concepts will be stored in the long-term memory of students. The obstacle faced by almost all physics teachers is the limited facilities and infrastructure in school laboratories. Only a limited number of schools can have the opportunity to have adequate laboratory equipment. Adequate school laboratories are those that can be used to conduct scientific experiments, observation, demonstrations and scientific activities related to teaching and learning activities (Herrani, 2015). Unfortunately, instead of carrying out experimental activities in the laboratory, teachers are more focused on completing curriculum targets by teaching concepts. This condition has an impact on the lack of actual experience in understanding the concepts of physics, especially in abstract concepts, one of which is the concept of energy.

Regarding the discussion of energy, the concept that has been available in simulation is the concept of mechanical energy. However, students will still experience difficulties because what is observed is simulated symptoms. The research results show that through practical activities with tangible objects obtain better learning outcomes than that by using simulations (Ariwibowo \& Desmira, 2016).

Mechanical energy is a natural phenomenon whose existence is real but it is difficult to observe the process by our senses. However, several findings have provided an opportunity to detect real symptoms of mechanical energy with the help of a sensor, one of which is ultrasonic sensor technology. Installation process of this sensor is quite simple and can be done easily by the teacher. Therefore it is necessary to optimize experimental tools in learning physics, especially in learning mechanical energy which is equipped with an ultrasonic sensor technology.

According to Budiarso and Agung (2015), an ultrasonic sensor is a device that functions to detect the distance of an object to another object in a different place. Ultrasonic sensors detect objects by sending and receiving reflections of ultrasonic waves (Pratama, Erik \& Tjetje, 2012). The ultrasonic sensor generally emits ultrasonic sound waves towards a target that reflects back the waves towards the sensor. The system measures the time needed to transmit and recapture the wave signal by the sensor as well as calculate the target distance using the speed of sound in the medium (Nataliana, Nandang, \& Aam, 2011).

Ultrasonic sensors provide convenience facilities in remote measurements. This sensor is perfect for measuring distances between moving or stationary objects. Ultrasonic sensors are also able to measure the distance of objects in the air through non-contact techniques so that these sensors can be used to measure distances with high accuracy, easy to use, and reliable (Latha, 2016). The advantages of this ultrasonic sensor are also reported by David as quoted in Shrivastava et al. (2010) that ultrasonic sensors are very versatile in distance measurement because ultrasonic waves can propagate both in air and in water. The ultrasonic sensor consists of a transmitter and receiver or transceiver (Kelemen et al., 2015) as in Figure 1 , which is useful for sending and receiving ultrasonic waves. 
Transmitter

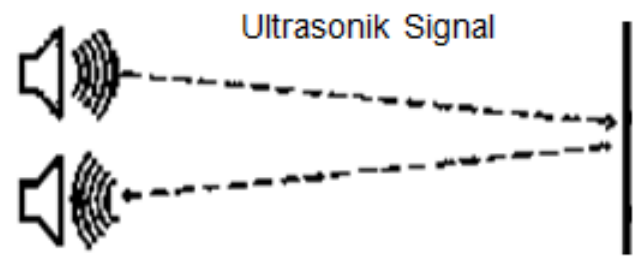

Receiver

Reflection Field

Figure 1. Schematic of an Ultrasonic Sensor

Judging from the shortcomings that emerged from the preliminary study, researchers developed a mechanical energy experiment tool by adding visualization features in graphical form. This feature will help students to understand changes in potential energy, kinetic energy and mechanical energy at all times when an object moves. Students can also observe the formed energy graph which is analyzed in theory by transferring data and accessing it directly to the laptop. Student activity in transferring and analyzing this data aims to help them practice interpreting experimental data. This activity is important because it refers to the results of Sharma's (2005) study that $46 \%$ of S1 and S2 students in physics education were still having difficulties in making graphics and also the students' ability to interpret graphs was very weak which was only $13 \%$. The same finding was also reported by Subali et al. (2017) that physics education students who take Basic Physics courses still have not mastered the competence of analyzing data and drawing conclusions from graphical displays. Therefore, the development of this experimental tool is expected to help and facilitate students in practicing graph analysis properly.

\section{METHOD}

This research has developed and produced a product that is a mechanical energy experimental device based on ultrasonic sensors equipped with an experimental module. This research includes research and development / R \& D. According to Sugiyono (2014) research and development methods are methods used to produce certain products and test the effectiveness of certain products with research procedures described in Figure 2.

After going through a series of calibration tests and expert tests and declared feasible to use, the experimental tool is tested to the user.
The trial for this user has used a sample of lab assistants and second semester physics education students of Semarang State University in the academic year $2017 / 2018$. They were asked to fill out a questionnaire as an empirical response after using the experimental tool.

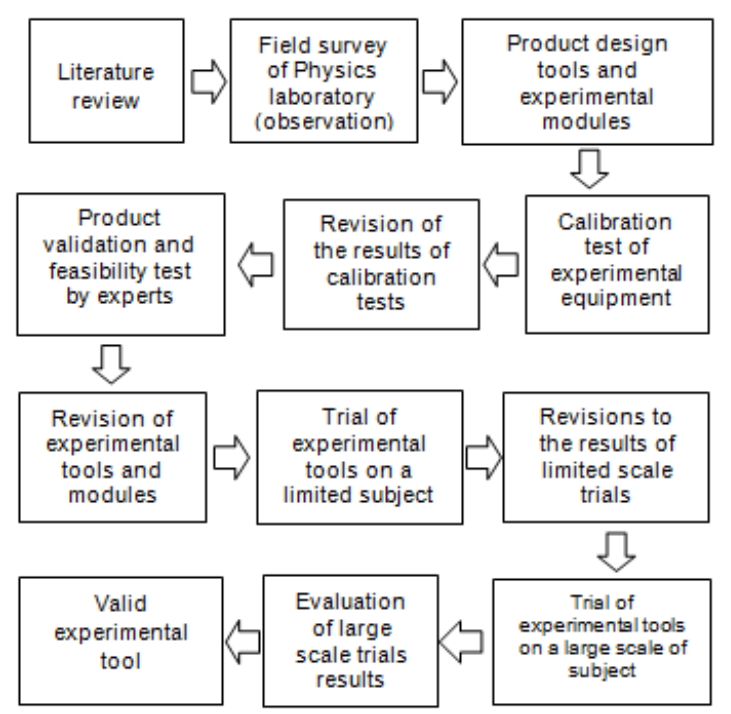

Figure 2. Research Design

\section{Library Studies and Laboratory Field Surve-} ys

This research begins with literature studies and field surveys in the laboratory to explore potential and problems as a database and raw material for designing media. Potential is anything that if utilized will have added value, while the problem is a deviation between reality and hope.

\section{Product Design}

After collecting various kinds of data needed, the next step is the process of creating experimental tools and modules. This process begins by drawing a blueprint of the experimental tool and developing the design into a ready-to-use experimental tool.

\section{Tool Calibration Test}

Tool calibration test is conducted to find out whether the tool can be used to determine the physical s (distance) magnitude or not. The method of calibration is by comparing the value of $s$ on the railroad track with the $s$ value detected on the ultrasonic sensor.

\section{Revision of Calibration Results}

Revision of the calibration results is used if the experimental tool used is not able to determine the physical quantity accurately. 


\section{Design Validation}

To test the feasibility and effectiveness of the experimental tools made, it is necessary to go through the validity stage (Sugiyono, 2014). This validation is useful to find out whether a product that is made is worth testing or not. Validation is done through expert judgment, namely validation based on physics learning media experts who are competent in their field.

\section{Revision of Experimental Tools and Modu- les}

After passing the validation process, it is known the weaknesses of the products made. The weakness is then reduced by repairing the parts that are still not functioning optimally.

\section{Limited Scale Trial}

The limited scale trial aims to determine the level of readability of the ultrasonic sensor based mechanical energy experiment tool. This limited-scale trial was conducted on 15 students in the 6th semester of the Department of Physics FMIPA UNNES who had taken Basic Physics courses. The students conducted experiments using tools and experimental modules that had been validated by experts.

\section{Small Scale Trial Revision}

After a small-scale trial had taken, a second experiment tool revised was carried out. Based on the findings and second revision step, the experimental tool can be used in large-scale tests as well as the initial stages of product implementation.

\section{Large Scale Trial}

Large-scale tests were conducted to determine whether the ultrasonic sensor-based mechanical energy experimental device was feasible or not feasible to be used in the experiment. There were 30 physics education students in semester 2 of Semarang State University 2017/2018 academic year and 4 laboratory assistants involved to do experiment using the developed tool. They were also given questionnaires about their experiences using an ultrasonic sensor based mechanical energy experiment tool.

\section{Evaluation Phase}

At the evaluation stage, data analysis of the research results obtained from the development of the tool was carried out, which was expected to obtain more accurate experimental data results
Analysis of expert validity and response of students and laboratory assistants in the form of descriptive analysis in the form of rating scale, ie each statement followed by several rubrics that show levels (Arikunto, 2013). The response or response to each statement is stated in 3 choices, rating scale is $3,2,1$ which shows the level of user satisfaction related to the experience of using the experimental tool. The overall calculation is done using the percentage (\%) of each response proposed by Sudijono (2009). The criteria obtained from the results of the questionnaire responses are presented in Table 1.

Table 1. Category Questionnaire Responses to The Quality of Experimental Tools

\begin{tabular}{ll}
\hline Percentage $(\%)$ & Criterias \\
\hline $25.00<$ skor $\leq 43,75$ & Low \\
$43,75<$ skor $\leq 62,50$ & Moderate \\
$62,50<$ skor $\leq 81,25$ & High \\
$81,25<$ skor $\leq 100$ & Very High \\
\hline
\end{tabular}

\section{RESULTS AND DISCUSSION}

The results of this study are an ultrasonic sensor based mechanical experiment experimental tool and equipped with an experimental module. The experimental tool has two main parts, namely the launching tube that has been connected to the track and the ultrasonic sensor box. The design of the experimental tool in question can be shown in Figure 3.

The tool was a development of a mechanical kit in the form of a railroad track, a railroad link and a dynamic train designed with the addition of a spring filled launching tube and equipped with ultrasonic sensors to measure distance and time. The experiment tool is made simple but still has a high level of accuracy. The following are the parts of the set of experimental energy based ultrasonic sensors.

- The track, as the train track dynamics.

- Link lane, connecting between lanes one with another lane.

- Throwing tube, this launcher tube contains a press spring that is connected to the launcher rod, serves to provide thrust to the object.

- Throwing rods, these iron rods are used to push objects which will move after the iron is pulled by a spring and into the tube.

- $\quad$ Throwing the thrower, this part is used to pull the launcher according to the distance 
the researcher wants.

- Bolt and propeller tube support, this section is used to tighten the throwing rod to keep it when the spring is pulled.

- Train dynamics, as motion objects are observed.

- Ultrasonic sensor, functions to detect time and distance.

- $\quad$ USB connecting cable, for connecting ultrasonic sensors to computers.

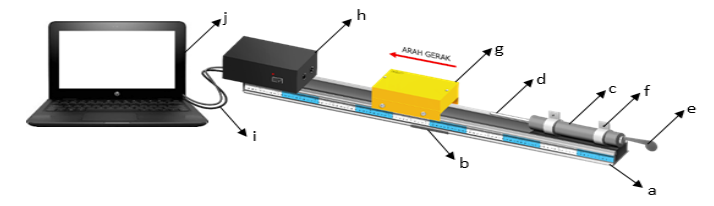

Figure 3. Design of Experimental Tools

The trajectory in Figure 3, serves as the motion track of the dynamic train which consists of several parts, namely the trajectory, the connecting lane and the trajectory buffer. The trajectory functions as the train's dynamic trajectory, the support of the throwing rod and also the distance measuring instrument when the distance of the spring presses with the crossbar on the track. This track consists of two pieces, each of which has a length of $50 \mathrm{~cm}$ and is connected with a lane link. The connecting lane is made of black plastic material and has a height of $2 \mathrm{~cm}$. The trajectory and connecting path can be seen in the control of the parts of Figure 3.

On one track it is connected with a thrower where the launcher consists of a throwing tube, throwing rod, throwing puller and bolt and propeller rod. The throwing tube contains a $20 \mathrm{~cm}$ long press spring which serves to give thrust to the object. The spring is associated with the launching rod and also the launcher made of iron with a diameter of $3 \mathrm{~mm}$ and 40 $\mathrm{cm}$ long. Throwing rods function to push objects that will later move because of the pulling of the throwing rod that has been linked to the press spring. While one set of throwers is supported with a band of zinc plates affixed to the track with nuts and bolts.

This experimental tool uses an ultrasonic sensor to detect distance and time when retrieving data. In the ultrasonic sensor box there is a push button switch button, this push button switch functions to turn on the counter machine. The counter machine will record the distance and time when the object moves. In this electronic sensor box, there is an Arduino elec- tronic circuit developed from an ATmega328 based microcontroller with $\mathrm{C}$ programming language so that it can automatically count distance and time instead of a stopwatch and can display the results on a computer. The electronic sensor box is shown in Figure 4.

The amplitude of the electrical signal produced by the receiving sensor unit depends on the proximity of the detected object and the quality of the transmitter sensor and receiver sensor. The sensoring process carried out on this sensor uses a reflection method to calculate the distance between the sensor and the target object. The distance between the sensors is calculated by multiplying half the time used by the ultrasonic signal on its journey from the sending circuit until it is received by the receiver circuit, with the propagation speed of the ultrasonic signal on the air propagation media. The principle of reflection from the ultrasonic sensor can be seen in Figure 1.

As in Figure 4, it can be seen that the ultrasonic sensor box section has a USB hole that serves to connect it to a computer using a USB cable. The supporting equipment needed in the experiment is a balance to measure the mass of the load before use and the waterpass to ensure that the track to be used is flat.

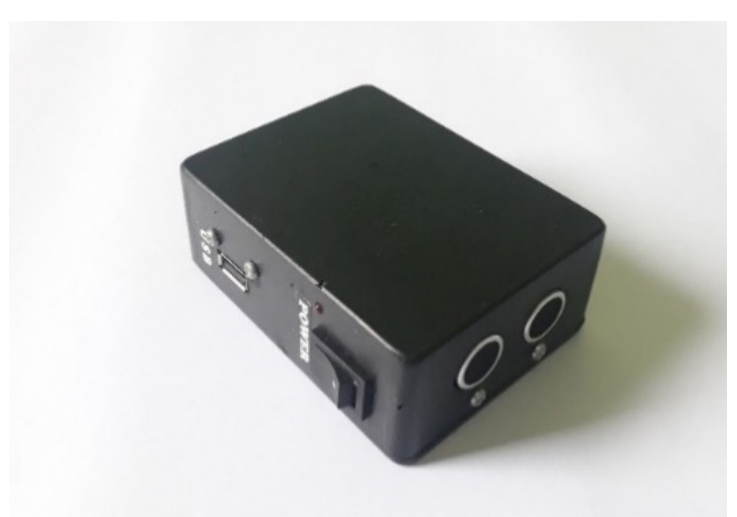

Figure 4. Ultrasonic Sensor Box

In the next stage, the mechanical energy experimental tool that has been made is tested by tool calibration and empirical test. The first trial is a calibration test on an experimental device based on ultrasonic sensors to compare the accuracy of the distance measuring instrument between using an ultrasonic sensor and using a ruler. Based on the results of the calibration test, observational data obtained are presented in Table 2. 
Table 2. Calibration Test Data

\begin{tabular}{cc}
\hline $\begin{array}{c}\text { The distance indi- } \\
\text { cated by the ruler } \\
(\mathrm{cm})\end{array}$ & $\begin{array}{c}\text { Distance indicated on } \\
\text { the sensor }(\mathrm{cm})\end{array}$ \\
\hline 2 & 2.02 \\
4 & 4.04 \\
6 & 6.06 \\
8 & 8.28 \\
9 & 9.09 \\
10 & 10.30 \\
12 & 12.32 \\
\hline
\end{tabular}

From the results of experimental data the calibration test it is found that the precision of the mechanical energy experimental device was $98.1 \%$, which meant that the experimental instrument was in the very feasible category.After conducting a calibration test, empirical tests have been carried out to determine the physical quantities associated with the experiment correctly and ensure that it is in accordance with the theory.

Empirical tests are also able to find out the accuracy of the experimental tools made. Based on the results of the empirical test, obtained observational data are presented in Table 3 with values of $t=\left(0.383 \pm 383 \times 10^{-4}\right) \mathrm{s}$ and the accuracy of the experimental equipment is high at $99.99 \%$ which means it is very feasible.

The feasibility test of the experimental tool along with the experimental module is carried out by a physicist who has qualified experts in the field of physics learning media. The feasibility test of the experimental tool includes aspects of economic value, practicality of the tool, conformity and accuracy, and the level of durability of the tool. The validation aspect of the experimental apparatus was in accordance with the Directorate General of High School Development (2011) and adapted to the mechanical energy experiment tool. The results of the feasibility test by expert validators can be shown in Table 4.
Table 4. Expert Validation of Experimental Tools

\begin{tabular}{ccc}
\hline $\begin{array}{c}\text { Assessment } \\
\text { Aspect }\end{array}$ & $\begin{array}{c}\text { Percentage } \\
(\%)\end{array}$ & Criteria \\
\hline $\begin{array}{c}\text { Conformity and } \\
\text { accuracy }\end{array}$ & 100 & Very feasible \\
$\begin{array}{c}\text { Strong and } \\
\text { sturdy }\end{array}$ & 100 & Very feasible \\
$\begin{array}{c}\text { Practicality } \\
\text { Total }\end{array}$ & 75 & Very feasible \\
\hline
\end{tabular}

Based on the data presented in Table 4, the results of the experimental test of mechanical energy included in the criteria are very feasible as an experimental support with an overall percentage of $93.75 \%$.

The mechanical energy experimental tool is accompanied by a manual which contains safety information, warnings, about mechanical energy and the operating methods of calculating the value of gravitational acceleration, maintenance, and experimental instructions. This manual is a support and contains various information about experimental devices and mechanical energy experimental procedures. In addition, the experimental instructions section was prepared to improve the user's science process skills in mechanical energy experiments.

The manual consists of two main parts, the first part contains an introduction to experimental tools, ranging from safety information to tool maintenance, while the second section contains instructions on mechanical energy experiments. The experimental instructions have at least parts consisting of the title of the experiment, purpose of the experiment, the theoretical description, experiment sketch, as wel as steps of the activity. The instructions for mechanical energy experiments are in the complete category. The characteristics of the manuals developed emphasize information about mechanical energy experiment tools,

Table 3. Empirical Test Data

\begin{tabular}{cccccccc}
\hline $\mathrm{s}(\mathrm{m})$ & $\mathrm{t} 1(\mathrm{~s})$ & $\mathrm{t} 2(\mathrm{~s})$ & $\mathrm{t} 3(\mathrm{~s})$ & $\mathrm{t}_{\text {average }}$ & Square of Sigma deviation & $\mathrm{s}$ deviation & Accuracy $(\%)$ \\
\hline 0.02 & 0.273 & 0.278 & 0.279 & 0.277 & 0.000021 & 0.001871 & 99.99 \\
0.04 & 0.288 & 0.291 & 0.293 & 0.291 & 0.000013 & 0.001472 & 99.99 \\
0.06 & 0.325 & 0.325 & 0.327 & 0.326 & 0.000003 & 0.000707 & 99.99 \\
0.08 & 0.382 & 0.384 & 0.388 & 0.385 & 0.000019 & 0.001780 & 99.99 \\
0.1 & 0.453 & 0.458 & 0.459 & 0.457 & 0.000021 & 0.001871 & 99.99 \\
0.12 & 0.536 & 0.537 & 0.603 & 0.559 & 0.000021 & 0.001871 & 99.99 \\
\hline
\end{tabular}


which is new for students. Complete information about the tool can make students more familiar with experimental tools before conducting experiments. This is in accordance with Yasin (2014) research that the module makes learning objectives clear, specific and can be achieved by students more directed to achieve competencies or abilities that are taught easily and directly. According to Widyaningrum et al. (2013) the achievement of student learning outcomes after the module has experienced a significant increase.

Information in the experimental module including safety information and warning uses is important because this experimental tool uses electrical assistance. In the module also presented a description of the mechanical energy experiment tool, starting from the design of the tool, parts of the tool, how to assemble the tool to how to operate it. There is also an analysis of changes in mechanical energy after obtaining observational data during experiments accompanied by a full explanation. In addition, a method of maintaining tools is provided, starting from how to clean up to how to store tools. This is intended to make the tool more durable.

The second part is experimental instructions. The purpose of this experiment is to direct students to develop science process skills in the aspect of formulating hypotheses related to how the experimental results will be obtained. The experimental instructions consist of the title of the experiment, objectives, theory, tools and materials, experimental steps, experimental hypotheses, observation data, data analysis, columns for analysis and discussion, columns for conclusions, and suggestion columns for experiments. In the material tools section and the experimental steps are made clear and accompanied by a sketch of the image to make it easier for students. Hypothesis questions are presented to stimulate students to be able to guess what will happen during the experiment based on their knowledge and are prepared based on science process skills. The module also equipped with observational data and data analysis in the form of tables to guide participants in the experiment. Finally, a discussion column, conclusions, and suggestions enrich the module.

Validation or due diligence of manuals is carried out by a media expert validator. The feasibility test of the manual includes aspects of content feasibility, feasibility of presentation, graphic feasibility, and language feasibility. The feasibility aspect of the manual is based on the
National Education Standards Agency (2006). Based on the results of the feasibility test obtained results as in Table 5.

Table 5. Validation of the Experimental Manual

\begin{tabular}{ccc}
\hline $\begin{array}{c}\text { Feasibility } \\
\text { Aspect }\end{array}$ & $\begin{array}{c}\text { Percetage } \\
(\%)\end{array}$ & Criteria \\
\hline Content & 95 & Very feasible \\
Presentation & 83.33 & Very feasible \\
Grapfic & 93.75 & Very feasible \\
Language & 87.5 & Very feasible \\
Total & 90.90 & Very feasible \\
\hline
\end{tabular}

Based on Table 5, the results of manual book validation are very feasible criteria as a complement to the experimental tool with an overall percentage of $90.90 \%$.

Small-scale trials are carried out to determine the feasibility of tools and module books in general to their use and to determine the level of readability of the tool. Small-scale trials were carried out with the participation of 15 physics students in the 6th semester and 8th semester majoring in physics. Students conduct experiments and then respond and comment on the improvement of ultrasonic sensor based mechanical energy experimental tools. In this small scale test the results were revised, namely the revision of the tool on the launcher part which initially used a spring balance and then revised so that it uses a spring-loaded paralon. After revision based on suggestions obtained from small-scale tests, then a largescale test is then carried out.

Large-scale trials are the stage of testing the use of experimental equipment on a large scale. This trial was conducted in 30 semester 2 students of physics education study programs and 4 laboratory assistants who were also students in the upper semester.

The results of large-scale trials are experimental reports, pretest scores, posttest scores, observation sheets of science process skills, and participant response sheets. Largescale tests not only measure the science process skills of students, but also to determine student responses to the use of experimental tools and manual books. The results of student responses to experimental devices are presented in Table 6.

The advantages of this experimental tool are able to measure the distance of objects and the time needed for an object when moving automatically and accurately related to 
Table 6. Responses of Students of the Small Scale (SS) and Large Scale (LS) Trials

\begin{tabular}{llllllll} 
& & \multicolumn{3}{c}{$\begin{array}{c}\text { Average } \\
\text { Assessment aspects }\end{array}$} & \multicolumn{2}{c}{$\begin{array}{c}\text { Percentage } \\
\text { Scores }\end{array}$} & Criteria \\
\cline { 2 - 5 } & SS & LS & SS & LS & \\
\hline $\begin{array}{l}\text { Experimental tools are very useful in learning phys- } \\
\text { ics }\end{array}$ & 2.87 & 2.91 & 95.56 & 96.97 & Very high \\
$\begin{array}{l}\text { The shape of the experimental device looks inter- } \\
\text { esting }\end{array}$ & 2.80 & 2.91 & 93.33 & 96.97 & Very high \\
$\begin{array}{l}\text { The experiment tool is easy to use in the process of } \\
\text { carrying out experiments }\end{array}$ & 2.53 & 2.70 & 84.44 & 89.90 & Very high \\
$\begin{array}{l}\text { Accuracy of measurements using experimental } \\
\text { tools }\end{array}$ & 2.60 & 2.58 & 86.67 & 85.86 & Very high \\
$\begin{array}{l}\text { The structure of the contents of the manual is com- } \\
\text { plete, coherent and neat }\end{array}$ & 2.80 & 2.82 & 93.33 & 93.94 & Very high \\
$\begin{array}{l}\text { The information provided in the manual makes the } \\
\text { experiment more efficient }\end{array}$ & 2.80 & 2.79 & 93.33 & 92.93 & Very high \\
$\begin{array}{l}\text { The statements and sentences in the manual are } \\
\text { easy to understand }\end{array}$ & 2.67 & 2.76 & 88.89 & 91.92 & Very high \\
$\begin{array}{l}\text { The size and model of letters used in the manual } \\
\text { are clearly and easily understood }\end{array}$ & 2.87 & 2.91 & 95.56 & 96.97 & Very high \\
$\begin{array}{l}\text { The contents of the material included in the manual } \\
\text { are easily understood and do not deviate from the }\end{array}$ & 2.93 & 2.94 & 97.78 & 97.98 & Very high \\
$\begin{array}{l}\text { concept } \\
\begin{array}{l}\text { Procedures and work steps are presented in a sys- } \\
\text { tematic and coherent manner }\end{array}\end{array}$ & 2.87 & 3.00 & 95.56 & 100 & Very high \\
\begin{tabular}{l} 
Average Scores \\
\hline
\end{tabular} & 2.77 & 2.83 & 92.44 & 94.34 & Very high \\
\hline
\end{tabular}

changes in mechanical energy and also able to know the effect of variations in object mass and variations in spring distance to changes in mechanical energy when moving objects. Another advantage of the tool is being able to display a graph of distance to time and also a graph of changes in mechanical energy to the time displayed on a computer so that observers can directly analyze the changes in mechanical energy every time.

Research on the development of experimental tools is similar to previous research studies from Subali et al. (2017). The development of computer-based free fall motion experiment tools can improve graphic reading skills better than traditional learning. Graphic literacy capabilities that can be improved are identifying variables, operating devices, reading measurement results, making graphs, formulating mathematical equations, predicting charts, deducing experimental results, and designing innovative devices, while graphics literacy capabilities that cannot be optimized are the ability to predict graphs because students don't have graphic reading experience. This finding was supported by research by Aslam et al. (2016) that by the development of graphical Ohm Law experimental tools, students can see directly the graph of the relationship between voltage and current, so that the graph of the relationship between voltage and current does not need to be manually in the picture to prove the linearity of the graph. According to Anugrah et al. (2015) the use of magnetic field experiment tools as a medium for high school physics learning that has been developed can increase student knowledge which can be seen from the increase in the pretest and posttest average values of 55.56 for pretest and 62.78 for posttest, which means an increase in knowledge with interpretation is being. In the other hand, Agustianti et al. (2015) stated that knowledge will be increasingly abstract if the message is only conveyed through verbal words and will be more concrete if delivered through direct experience, one of which is experimentation. For this reason, the need for optimization of experimental tools that can provide conveni- 
ence and interest for individuals to learn about, resulting in better learning.

The obstacles encountered during the implementation of the experimental tool are summarized based on the results of interviews with several students who were respondents to the experiment. These constraints include the experimental tool that is classified as new and first at Semarang State University, Indonesia has never been developed before, so respondents experienced some difficulties when taking variation data at the beginning of the experiment. The variation in question is in the form of distance variations and mass variations. This is anticipated by displaying the maximum distance that can be detected by the sensor so that the error in distance variations that cause the graph cannot appear can be minimized.

Based on the theory of education, practicum tools must be able to function optimally in experimental activities. But in the implementation there are obstacles, namely the sensor sometimes does not work properly so that the graph of energy to time cannot appear on the computer screen. This is anticipated by attaching an ultrasonic sensor to a pedestal so that the sensor can be still but can be moved according to the desired distance. In addition, observers were encouraged to minimize body movements during data retrieval other than research objects so that sensors only detect research objects.

\section{CONCLUSION}

Through development research carried out it has been successfully developed an ultrasonic sensor based experiment on mechanical energy along with a mechanical energy experiment module. The experimental tool has gone through calibration tests and empirical tests with high accuracy criteria. The expert validator stated that the experimental tools and experimental modules were very feasible to be used in physics learning activities. This was also stated by the user and they gave a positive response to the experimental tool. Constraints encountered during the implementation of the mechanical energy experiment tool were ultrasonic sensors that were too sensitive to the movement around so that the resulting graph was less suitable. In addition, because this experimental tool is relatively new, respondents are still struggling to vary the variables so that the graph becomes easily observed.

\section{REFERENCES}

Agustianti, D., Cecep E. R. \& Hadi N. (2015). Pengembangan Alat Eksperimen Melde Sebagai Media Pembelajaran Fisika Sma. Prosiding Seminar Nasional Fisika (E-Journal) SNF2015. IV.

Anugrah, M. I., Vina S. \& Hadi N. (2015). Pengembangan Alat Eksperimen Medan Magnet Sebagai Media Pembelajaran Fisika SMA. Prosiding Seminar Nasional Fisika (E-Journal) SNF2015. IV.

Aslam., S., Darsikin. \& Unggul W. (2016). Pengembangan Alat Eksperimen Hukum Ohm Berbasis Grafik Menggunakan Mikrokontroler Pada Mahasiswa Calon Guru Fisika. Jurnal Pendidikan Fisika Tadulako. 4(1), 21-26.

Arikunto, S. (2013). Dasar-dasar Evaluasi Pendidikan. Jakarta: Penerbit Bumi Aksara.

Ariwibowo, D. \& Desmira. (2016). Pengembangan Aplikasi Simulasi Perhitungan Energi Mekanik Berdasarkan Hukum Kekekalan Energi Dalam Proses Belajar Siswa. Jurnal Prosisko. 3(1), 12.

Awal, S., Ahmad Y. \& Bunga D. A. (2012). Peranan Metode Pictorial Riddle Terhadap Penguasaan Konsep Fisika Pada Siswa SMAN 1 Bontonompo. Jurnal Pendidikan Fisika. 4(2), 250.

Budiarso, Z. \& Agung P. (2015). Implementasi Sensor Itrasonik Untuk Mengukur Panjang Gelombang Suara Berbasis Mikrokontroler. Jurnal Teknologi Informasi DINAMIK. 20(2), 172.

Badan Standar Nasional Pendidikan. (2006). Instrument Penilaian Buku Teks Pelajaran SMP/ MTs Dan SMA/MA Tahap II Komponen Kegrafikan.

Direktorat Jenderal Pembinaan Sekolah Menengah Atas. (2011). Pedoman Pembuatan Alat Peraga Fisika.

Herrani, C. R. (2015). Penggunaan Virtual Lab untuk Meningkatkan Keterampilan Mahasiswa Pendidikan Biologi Dalam Menggunakan Alat-Alat Mikrobiologi. Widya Darma Jurnal Kependidikan. 27(2), 162.

Kelemen, M., Ivan, V., Tatiana, K., Lubica, M., Peter, F., Tomas, L. \& Milan, L. (2015). Distance Measurement via Using of Ultrasonic Sensors. Journal of Automation and Control 3(3), 71.

Latha, N. A., Murthy, B. R. \& Khumar, K. B. (2016). Distance Sensing with Ultrasonic Sensor and Arduino. International Journal of Advanse Research, Idean and Inovation in Technology 2(5), 1.

Nataliana, D., Nandang T. \& Aam A. M. (2011). Perancangan Prototype Deteksi kecepatan Kendaraan Menggunakan RFID Berbasis Mikrokontroler Atmega 8535. Jurnal Informatika. 3(1), 73.

Pratama H., Erik H. \& Tjetje G. (2012). Akuisisi Data Kinerja Sensor Ultrasonik Berbasis Sistem 
Komunikasi Serial Menggunakan Mikrokontroler Atmega 32. ELECTRANS. 11(2), 37.

Rosenblum, B. \& Kuttner, F. 2006. Quantum Enigma: Physics encounters Consciousness. Oxford University Press. New York.

Setiawan, A., Sutarto. \& Indrawati. (2012). Metode Eksperimen Dalam Pembelajaran Pengantar Fisika SMA: Studi Pada Konsep Besaran Dan Satuan Tahun Ajaran 2012-2013. Jurnal Pembelajaran Fisika. 1(3), 285.

Sharma, S.V. (2005). High School Student Interpreting Tabels and Graph: Implication for Reseach. International Journal of Science and Mathematics Education, 4(2), 241-268.

Shrivastava, A. K., Verma, A. \& Singh, S. P. (2010). Distance Measurement of an Object or Obstacle by Ultrasound Sensors using P89C51RD2. International Journal of Computer Theory and Engineering 2(1), 64.

Silberman, Mel. (2006). Training the Active Training Way: 8 Strategies to Spark Learning and Change. San Fransisco: Pfeiffer.
Subali, B., D. Rusdiana, H. Firman., I. Kaniawati. \& Ellianawati. (2017). Computer-Based Experiment of Free Fall Movement to Improve the Graphical Literacy. Jurnal Pendidikan IPA Indonesia. 6 (1), 41-48.

Sudijono, A. (2009). Pengantar Evaluasi Pendidikan. Jakarta: PT Raja Grafindo Persada.

Sugiyono. (2014). Metode Penelitian Kuantitatif kualitatif dan R\&D. Bandung: ALFABETA.

Suparno, P. 2007. Metode Penelitian Pendidikan Fisika. Yogyakarta: Universitas Sanata Dharma.

Widyaningrum, R., Sarwanto, Karyanto, P. (2013). Pengembangan Modul Berorientasi Poe (Predict, Observe, Explain) Berwawasan Lingkungan Pada Materi Pencemaran Untuk Meningkatkan Hasil Belajar Siswa. BIOEDUKASI. 6(1), 100-117.

Yasin, M. 2014. Pengembangan Modul Transmisi Otomatis Mobil Untuk Meningkatkan Kualitas Hasil Belajar Siswa Kelas Xi Di Sekolah Menengah Kejuruan. Jurnal Pendidikan 3(1), 121-129. 